\title{
Composition and evaluation of the antimicrobial activity of the essential oil of Senecio selloi Spreng DC.
}

SILVA, G.N.S. ${ }^{1}$; SPADER, T.B. ${ }^{2}$; ALVES, S.H. ${ }^{2}$; MALLMANN, C.A. ${ }^{3}$; HEINZMANN, B.M. ${ }^{2 *}$

${ }^{1}$ Departamento de Farmácia Industrial, Centro de Ciências da Saúde,Universidade Federal de Santa Maria, Avenida Roraima, Prédio 26, Campus Universitário, 97105-900, Santa Maria, RS, Brasil. 'Departamento de Microbiologia e Parasitologia, Centro de Ciências da Saúde, Universidade Federal de Santa Maria, Avenida Roraima, Prédio 20, Sala 4139, Campus Universitário, 97105-900, Santa Maria, RS, Brasil. ${ }^{3}$ Departamento de Medicina Veterinária Preventiva, Centro de Ciências Rurais, Universidade Federal de Santa Maria, Avenida Roraima, Prédio 44, Campus Universitário, 97105-900, Santa Maria, RS, Brasil.

\begin{abstract}
The essential oil of the aerial parts of Senecio selloi Spreng. DC. was extracted by hydrodistillation and analyzed by GC/MS. Nineteen compounds were identified, representing $99.9 \%$ of the total. The main compounds were found to be sesquiterpene hydrocarbons $(71.3 \%)$, most of them with a bisabolane skeleton (59.4\%). The major constituent was $\alpha$-zingiberene $(54 \%)$, followed by monoterpene $\alpha$-isolimonene $(16 \%)$. The essential oil was also tested against two Gram-positive and two Gram-negative bacterial species, three yeasts, and an algae. From the strains assayed, only Bacillus subtilis ATCC 6633 showed susceptibility (MIC and MBC = $4400 \mu \mathrm{g} / \mathrm{mL}$ ) to the essential oil.
\end{abstract}

Key words: Antimicrobial activity, essential oil, Senecio selloi Spreng. DC.

RESUMO: Composição e avaliação da atividade antimicrobiana do óleo essencial de Senecio selloi Spreng DC. O óleo essencial das partes aéreas de Senecio selloi Spreng DC. foi extraído por hidrodestilação e analisado por CG/EM. Dezenove constituintes foram identificados, representando $99,9 \%$ do total. Os principais compostos fornecidos foram sesquiterpenos hidrocarbonetos $(71,3 \%)$, a maioria destes com esqueleto bisabolano $(59,4 \%)$. O constituinte majoritário foi a-zingibereno (54\%), seguido do monoterpeno a-isolimoneno (16\%). O óleo essencial foi testado contra duas cepas Gram-positivas e duas Gram-negativas, três fungos e uma alga. De todas as linhagens testadas somente Bacillus subtilis ATCC 6633 mostrou suscetibilidade $(\mathrm{CIM}$ e $\mathrm{CBM}=4400 \mu \mathrm{g} / \mathrm{mL})$ para o óleo essencial.

Palavras-chave: Atividade antimicrobiana, óleo essencial, Senecio selloi Spreng. DC.

\section{INTRODUCTION}

According to Bolzan et al (2007), 46 Latin American Senecio species are used for therapeutic purposes, including the treatment of fungal skin infections (Portillo et al., 2001), pneumonia (Hammond et al., 1998) and antiseptic (Bah et al., 1994). This information suggests antifungal and/or antibacterial activities for preparations obtained from this species.

The genus Senecio (Asteraceae) is constituted of about 2000 species worldwide, 85 of which are found in southern Brazil and of these, 33 are native of the state of Rio Grande do Sul (Cabrera \& Klein, 1975). Despite the large number of species and its classification in a botanical family which is rich in essential oils, there are only few reports on the composition and biological activities of this group of compounds for the genus.

Essential oils are a mixture of volatile components with different biological functions, which are necessary for the survival of the produced plant species. They often play a crucial role in the defense against microorganisms (Siqui et al., 2000). The essential oils have been used for bactericidal, virucidal, fungicidal, antiparasitic, insecticidal, medicinal and cosmetic applications, yet in pharmaceutical, sanitary, cosmetic, agricultural and food industries (Bakkali et al., 2008).

This paper reports the chemical analysis of the essential oil obtained from aerial parts of Senecio selloi Spreng. DC. and its antimicrobial evaluation.

Recebido para publicação em 27/05/2011

Aceito para publicação em 31/01/2013

Rev. Bras. PI. Med., Campinas, v.15, n.4, p.503-507, 2013. 
This species is popularly known as catião-melado and grows as shrub in southern Brazil (Rücker et al., 1999). For this species, the literature describes peroxides with sesquiterpenic structure (Rücker et al., 1996; Heinzmann, 1996) as well as triterpenoids (Rücker et al., 1999; Heinzmann, 1996; Rücker et al., 2003).

\section{MATERIAL AND THE METHODS}

\section{Plant material}

Aerial parts of Senecio selloi Spreng. DC. were collected in November 2006 in Guaíba, state of Rio Grande do Sul, Brazil. The plant material was identified by Prof. N. I. Matzenbacher, Dr. (Graduate Botany Program, UFRGS). A voucher specimen (SMDB 10206) was deposited in the herbarium of the Department of Biology, UFSM.

\section{Essential oil extraction and analysis}

The essential oil was obtained from the fresh aerial parts $(2.507 \mathrm{~kg})$ by hydrodistillation using Clevenger type apparatus for $2 \mathrm{~h}$ (Farmacopéia Brasileira, 2000) and then stored at $-4^{\circ} \mathrm{C}$ in amber glass bottles. Its yield was calculated as the ratio between the weight of the fresh plant and weight of the essential oil obtained (\% w/w).

GC-MS TIC analysis was performed using an Agilent-6890 gas chromatograph coupled with an Agilent 5973 mass selective detector, under the following conditions: HP5-MS column (5\%-phenyl $95 \%$-methylsiloxane, $30 \mathrm{~m} \times 0.25 \mathrm{~mm} \times 0.25 \mathrm{~mm}$ ); EIMS: $70 \mathrm{eV}$. Operating conditions: split inlet 1:100; temperature program, $40-260{ }^{\circ} \mathrm{C} ; 40{ }^{\circ} \mathrm{C}$ for $4 \mathrm{~min}$; ramp rate, $4^{\circ} \mathrm{C} / \mathrm{min}$; carrier gas He; flow rate, 1 $\mathrm{mL} / \mathrm{min}$; injector and detector temperature, $220^{\circ} \mathrm{C}$; interface temperature $250^{\circ} \mathrm{C}$; Databank NIST, 1998.

The constituents of the essential oils were identified based on retention index (RI), determined using a calibration curve of a homologous series of n-alkanes $\left(\mathrm{C}_{8}-\mathrm{C}_{32}\right)$ injected under the same chromatographic conditions of samples and models fragmentation of mass spectra, both compared with literature data. (Adams, 2001) (Table 1).

The concentration of constituents was calculated using the full area of their peaks, related to the total area of all the constituent sample, obtained by analysis using gas chromatograph.

\section{Antimicrobial activity}

The microorganisms used in the test are cataloged strains and clinical isolates, and they are listed in Table 2. The antimicrobial activity of the essential oil was determined by the broth microdilution method (NCCLS, 1997; NCCLS, 2002). Initially, the essential oil was dissolved in methanol in order to obtain a stock solution which was diluted $(1: 100)$ in the appropriate medium; Mueller-Hinton broth for bacterial strains and buffered RPMI 1640 broth for yeasts. From these, serial dilutions were prepared in 96-well microtiter trays.

Bacterial strains and yeasts were grown in Mueller-Hinton $\left(24 \mathrm{~h} / 35^{\circ} \mathrm{C}\right)$ and Sabouraud dextrose agar $\left(48 \mathrm{~h} / 35^{\circ} \mathrm{C}\right)$, respectively. Bacterial suspensions of $0.5 \mathrm{McF}$ arland standard turbidity $\left(1 \times 10^{8} \mathrm{CFU} / \mathrm{mL}\right)$ were prepared by dilution with saline, and later diluted (1:100) with Mueller-Hinton broth $\left(1 \times 10^{6} \mathrm{CFU} / \mathrm{mL}\right)$. Aliquots of $10 \mathrm{~mL}\left(1 \times 10^{4}\right.$ $\mathrm{CFU} / \mathrm{mL}$ ) of inoculum were added to each well of the microtiter tray already containing $200 \mathrm{~mL}$ of the medium plus different concentrations of the essential oil. In parallel, yeast suspensions were prepared by dilution with $0.85 \% \mathrm{NaCl}$ solution and adjusted to 0.5 McFarland standard turbidity $\left(1 \times 10^{6}\right.$ to $5 \times 10^{6} \mathrm{CFU} /$ $\mathrm{mL}$ ). These suspensions were diluted with sterilized water (1:50) and buffered RPMI 1640 broth (1:20), resulting in $1.0 \times 10^{3}$ to $5.0 \times 10^{3} \mathrm{CFU} / \mathrm{mL}$. $100 \mu \mathrm{L}$ of the inoculum was added to each well of the microtiter plate already containing $100 \mu \mathrm{L}$ of the essential oil solution in different concentration. The microplates with bacterial strains were incubated for $24 \mathrm{~h}$ at 35 ${ }^{\circ} \mathrm{C}$. Those with yeasts were incubated for $48 \mathrm{~h}$ at 35 ${ }^{\circ} \mathrm{C}$. The same tests were performed simultaneously for inoculum growth and sterility control. The final concentration of methanol did not exceed $1 \%$ and did not affect the growth of the microorganisms. The algae Prototeca zopfii was assayed in the same way as yeasts were described.

The minimum inhibitory concentration (MIC) was determined as the lowest concentration of essential oil that completely inhibited visible growth of microorganisms. To determine the minimum bactericidal and fungicidal concentration (MBC/ MFC), $10 \mathrm{~mL}$ broth was taken from each well without microbial growth and inoculated in Mueller-Hinton and Sabouraud dextrose agar, respectively. The plates were incubated for $48 \mathrm{~h}$ at $35^{\circ} \mathrm{C}$ until they were read. MBC and MFC were defined as the lowest concentration of the essential oil capable of killing the inoculum.

\section{RESULTS AND DISCUSSION:}

The essential oil of the fresh aerial parts of S. selloi gave a yield of $0.0035 \%$, which can be considered low if compared with the yields obtained for the essential oils of the aerial parts of other Senecio species (Francescato, 2007). Results of the chemical analysis of the essential oil are shown in Table 1. In the oil, we observe the prevalence of sesquiterpenes, fact that was also reported for the essential oil of several species of Senecio (Francescato, 2007; Murari et al., 2008). Among 
TABLE 1. Composition of the essential oil of the aerial parts of $S$. selloi. $\mathrm{KI}=$ Literature Kovats index (Adams, 2001) $\mathrm{KI}_{\mathrm{C}}=$ calculated Kovats index

\begin{tabular}{|c|c|c|c|}
\hline Constituents & KI & KIc & Percentage (\%) \\
\hline $\begin{array}{c}\text { Monoterpenes } \\
\text { Acyclic derivatives }\end{array}$ & & & \\
\hline $\begin{array}{c}\text { Z- } \beta \text {-Ocimene } \\
\text { Monocyclic derivativ }\end{array}$ & 1037 & 1044 & 1.8 \\
\hline $\begin{array}{l}\text { Camphene } \\
\alpha \text {-Isolimonene }\end{array}$ & $\begin{array}{l}954 \\
985\end{array}$ & $\begin{array}{l}958 \\
992\end{array}$ & $\begin{array}{l}3.4 \\
16\end{array}$ \\
\hline $\begin{array}{c}\gamma \text {-Terpinene } \\
\text { [p-Mentha-3,8-diene] }\end{array}$ & $\begin{array}{r}1060 \\
1073 \\
\text { eenes) }\end{array}$ & $\begin{array}{l}1064 \\
1075\end{array}$ & $\begin{array}{c}1.7 \\
5.7 \\
28.6\end{array}$ \\
\hline \multicolumn{4}{|l|}{$\begin{array}{l}\text { Sesquiterpenes } \\
\text { Acyclic derivatives }\end{array}$} \\
\hline \multicolumn{4}{|l|}{ Bisabolane derivatives } \\
\hline$\alpha$-Curcumene & 1481 & 1489 & 4.1 \\
\hline$\alpha$-Zingiberene & 1494 & 1498 & 54 \\
\hline$\beta$-Curcumene & 1516 & 1508 & 1.3 \\
\hline \multicolumn{4}{|l|}{ Cadinane derivatives } \\
\hline$\alpha$-Cubebene & 1351 & 1351 & 0.04 \\
\hline$\alpha$-Copaene & 1377 & 1377 & 0.40 \\
\hline $\begin{array}{l}\text { Zonarene } \\
\text { Carvophvllane deriva }\end{array}$ & \multicolumn{2}{|c|}{ Caryophyllane derivatives } & 1.3 \\
\hline Caryophyllene Oxide & 1583 & 1591 & 0.6 \\
\hline E- $\beta$-Caryophyllene & 1419 & 1421 & 4.1 \\
\hline \multicolumn{3}{|c|}{ Germacrane derivatives } & 0.6 \\
\hline$\beta$-Elemene & 1391 & 1394 & 0.1 \\
\hline $\begin{array}{c}\text { Germacrene D } \\
\text { Other }\end{array}$ & 1485 & 1484 & 4.4 \\
\hline Isocomene & 1388 & 1387 & 0.05 \\
\hline Acorenol & 1633 & 1638 & 0.15 \\
\hline \multicolumn{2}{|c|}{$\Sigma$ (\% total of sesquiterpenes) } & & 71.3 \\
\hline UC & - & 1476 & 0.1 \\
\hline UC & - & 1479 & 0.12 \\
\hline
\end{tabular}

UC: Unidentified Compound

TABLE 2. Minimum inhibitory concentration values of the essential oil of Senecio selloi against bacteria, yeasts and algae.

\begin{tabular}{|c|c|c|c|}
\hline \multirow[t]{2}{*}{ Microorganisms } & \multicolumn{2}{|c|}{ Essential oil } & Antibiotics control \\
\hline & $\mathrm{MIC}(\mu \mathrm{g} / \mathrm{mL})$ & $\mathrm{MBC}(\mu \mathrm{g} / \mathrm{mL})$ & $\mathrm{MIC}(\mu \mathrm{g} / \mathrm{mL})$ \\
\hline Staphylococcus aureus ATCC 25923 & $>4400$ & $>4400$ & 2 \\
\hline Escherichia coli ATCC 25922 & $>4400$ & $>4400$ & 8 \\
\hline \multirow[t]{2}{*}{ Bacillus subtilis ATCC 6633} & 4400 & 4400 & 1 \\
\hline & $\mathrm{MIC}(\mu \mathrm{g} / \mathrm{mL})$ & $\mathrm{MBC}(\mu \mathrm{g} / \mathrm{mL})$ & MIC $(\mu \mathrm{g} / \mathrm{mL})$ Ceftiofur \\
\hline \multirow[t]{2}{*}{ Pseudomonas aeruginosa ATCC 27853} & $>4400$ & $>4400$ & 32 \\
\hline & $\mathrm{MIC}(\mu \mathrm{g} / \mathrm{mL})$ & MFC $(\mu \mathrm{g} / \mathrm{mL})$ & MIC $(\mu \mathrm{g} / \mathrm{mL})$ Fluconazole \\
\hline Candida albicans ATCC 44373 & $>2200$ & $>2200$ & 8 \\
\hline Candida glabrata ATCC 10231 & $>2200$ & $>2200$ & 16 \\
\hline \multirow[t]{2}{*}{ Saccharomyces cerevisiae ATCC 2601} & $>2200$ & $>2200$ & 2 \\
\hline & $\mathrm{MIC}(\mu \mathrm{g} / \mathrm{mL})$ & MFC $(\mu \mathrm{g} / \mathrm{mL})$ & MIC $(\mu \mathrm{g} / \mathrm{mL})$ Amphotericin B \\
\hline Prototheca zopfii (clinical isolated) & $>2200$ & $>2200$ & 4 \\
\hline
\end{tabular}


the sesquiterpenes, the derivatives of bisabolane skeleton predominate with $59.4 \%$ of the composition of oil, being a-zingiberene the major component, with $54 \%$.

Results concerning the evaluation of the antimicrobial activity are shown in Table 2.

The essential oil of the aerial parts of $S$. selloi presented activity only against one Grampositive strain, Bacillus subtilis ATCC 6633 , with values for MIC and MBC of $4400 \mathrm{mg} / \mathrm{mL}$. B. subtilis is a microorganism of interest because of its wide industrial application, its similarity to pathogenic strains, and its role as a model organism for Grampositive sporulating bacteria (Henry et al., 2009).

The absence of susceptibility of Gramnegative bacteria against the essential oil evaluated is not surprising because of the dual membrane presented by these microorganisms, which prevents the penetration of various antimicrobial agents. Additionally, their periplasmic space contains enzymes that are capable of breaking down foreign molecules introduced into the environment (Duffy \& Power, 2001).

Different authors attribute the ability of essential oils to inhibit the growth of microorganisms to the hydrophobicity of their constituents. This feature would allow their partition in the bilipid layer cell membrane, increasing permeability and leading to loss of vital cell content (Burt, 2004; Juven et al., 1994; Kim et al., 1995). However, other studies have reported the relevance of an oxygen function in the molecule for this activity. According to Dorman \& Deans (2000), alcohols have recognized bactericidal activity against vegetative cells, acting as protein denaturing agents, solvents or dehydrating agents. Other authors have reported that components of essential oils containing phenolic or alcoholic groups exhibit more pronounced inhibitory effects on microbial growth, followed by aldehydes and ketones (Griffin et al., 1999). When hydrophobicity is crucial for the antimicrobial activity, a good antimicrobial activity for the essential oil of S. selloi would be expected, since the major constituents are hydrocarbons. In contrast, the antibacterial activity was detected only for a single strain of Gram-positive bacteria and only in high concentrations.

Some peculiarities of essential oils such as volatility, low solubility in water and their complexity, significantly interfere with the results of tests for evaluation of antimicrobial activity. Other important factors to take into consideration are the characteristics of each microorganism and the oil to be analyzed. In experiments with fungi, for example, we must take into account the incubation time of 48 hours, which may interfere with the results due to the decomposition or evaporation of oil during the test period (Nascimento et al., 2007).
The absence of oxygenated compounds in the oil is another likely explanation for the high values of MIC and MBC detected in this study (Murari et al., 2008). Therefore, the results described in this work reinforce the importance of the oxygenated function to the antimicrobial activity of essential oils. Although we did not evaluate the antimicrobial activity of the essential oil of $S$. selloi against phytopathogens, the results obtained suggest that its components do not act in plant defense against microorganisms, however, it must have other biological functions. In fact, the literature describes different biological activities for its major constituent, zingiberene, which shows insecticide, repellent and antifeedant activities (Antonious \& Kochhar, 2003).

\section{ACKNOWLEDGMENTS}

Prof. Dr. N. I. Matzenbacher for location and identification of the plant material.

\section{REFERENCE}

ADAMS, R.P. Identification of essential oil components by gas chromatographyl quadrupole mass spectroscopy. Allured Publishing Corporation: Carol Stream, Illinois, 2001, 456p.

ANTONIOUS, G.F.; KOCHHAR, T.S. Zingiberene and curcumene in wild tomato. Journal of Environmental Science and Health, Part B: Pesticides, Food Contaminants, and Agricultural Wastes, v.38, n.4, p.489-500, 2003.

BAH, M.; BYE, R.; PEREDA-MIRANDA, R. Hepatotoxic pyrrolizidine alkaloids in the Mexican medicinal plant Packera candidissima (Asteraceae: Senecioneae). Journal of Ethnopharmacology, v. 43, n.1, p.19-30, 1994.

BAKKALI, F.; AVERBECK, S.; AVERBECK, D.; IDAOMAR, $M$. Biological effects of essential oils $-A$ review. Food and Chemical Toxicology, v.46, n.2, p.446-75, 2008.

BOLZAN, A.A.; SILVA, C.M.; FRANCESCATO, L.N.; MURARI, A.L.; SILVA, G.N.S.; HELDWEIN, C.G.; HEINZMANN, B.M. Espécies de Senecio na medicina popular da América Latina e riscos relacionados a sua utilização. Latin American Journal of Pharmacy (formerly Acta Farmacéutica Bonaerense), v. 26, n.4, p. 619-25, 2007.

Brasil; Farmacopéia Brasileira, 4th Edition. São Paulo: Atheneu; 2000.

BURT, S. Essential oils: their antibacterial properties and potential applications in foods - a review. International Journal of Food Microbiology,v.94, n.3, p.223-53, 2004.

CABRERA, A.L.; KLEIN, R.M. "Compostas" em "Flora Ilustrada Catarinense" (P.R., Reitz), Herbário Barbosa Rodrigues, Itajaí, 1975.

DORMAN, H.J., DEANS, S.G. Antimicrobial agents from plants: antibacterial activity of plant volatile oils. Journal of Applied Microbiology, v.88, n.2, p.308-16, 2000.

DUFFY, C.F.; POWER, R.F. Antioxidant and antimicrobial properties of some Chinese plant extracts. International

Rev. Bras. PI. Med., Campinas, v.15, n.4, p.503-507, 2013. 
Journal of Antimicrobial Agents, v.17, n.6, p.527-29, 2001.

FRANCESCATO, L.N. Constituintes de Senecio heterotrichius DC.: Isolamento, elucidação estrutural, derivatizações e avaliação da atividade antimicrobiana; estudo dos constituintes voláteis de outras espécies de Senecio. 2007. Dissertação de Mestrado, Programa de Pós-graduação em Ciências Farmacêuticas, Departamento de Farmácia Industrial, Universidade Federal de Santa Maria, Santa Maria.

GRIFFIN, S.G.; GRANT WYLLIE, S.; MARKHAM, J.L.; $\mathrm{LEACH}$, D.N. The role of structure and molecular properties of terpenoids in determining their antimicrobial activity. Flavour and Fragrance Journal, v.14, n.5, p.322-32, 1999.

HAMMOND, G.B.; FERNÁNDEZ, I.D.; VILLEGAS, L.F.; VAISBERG, A.J. A survey of traditional medicinal plants from the Callejón de Huaylas, Department of Ancash, Perú. Journal of Ethnopharmacology, v.61, n.1, p.17-30, 1998.

HEINZMANN, B.M. Inhaltsstoffe aus Senecio selloi Spreng de Candolle. 1996. 149 p. Tese de Doutorado, Programa de Pós Graduação em Ciências Naturais e Exatas Química Farmacêutica, Universidade de Bonn, Bonn.

JUVEN, B.J.; KANNER, J.; SCHVED, F.; WEISSLOWICZ, $H$. Factors that interact with the antibacterial action of thyme essential oil and its active constituents. Journal of Applied Microbiology, v.76, n.6, p.626-31, 1994.

HENRY, C.S.; ZINNER, J.F.; COHOON, M.P.; STEVENS,

R.L. iBsu1103: a new genome-scale metabolic model of Bacillus subtilis based on SEED annotations. Genome Biology, v.10, n.69, p.1-15, 2009.

KIM, E.; NIETHAMMER, M.; ROTHSCHILD, A.; JAN, Y.N.; SHENG, M. Clustering of Shaker-type K+ channels by interaction with a family of membrane-associated guanylate kinases. Nature, v.378, p.85-8, 1995.

MURARI, A.L.; CARVALHO, F.H.; HEINZMANN, B.M.
Composição e atividade antibacteriana dos óleos essenciais de Senecio crassiflorus var. crassiflorus. Química Nova, v.31; n.5, p.1081-4, 2008.

NASCIMENTO, P.F.C.; NASCIMENTO,A.C.; RODRIGUES, C.S.; ANTONIOLLI, Â.R.; SANTOS, P.O.; BARBOSA JÚNIORA.M; TRINDADE, R.C. Atividade antimicrobiana dos óleos essenciais: uma abordagem multifatorial dos métodos. Revista Brasileira de Farmacognosia, v.17, n.1, p.108-13, 2007.

National Committee for Clinical Laboratory Standards. Methods for dilution antimicrobial susceptibility tests for bacteria that grows aerobically. Approved Standard M7A4, 5th edition. Wayne, Pennsylvania: NCCLS, 1997.

National Committee for Clinical Laboratory Standards. Reference method for broth dilution antifungical susceptibility testing of yeasts. Approved Standard M27-A2, 2nd edition. Wayne, Pennsylvania: NCCLS, 2002.

PORTILLO, A.; VILA, R.; FREIXA, B.; ADZET, T.; CAÑIGUERAL, S. Antifungal activity of Paraguayan plants used in traditional medicine. Journal of Ethnopharmacology, v.76, n.1, p.93-8, 2001.

RÜCKER, G.; SCHENKEL, E.P.; MANNS, D.; MAYER, R.; HEIDEN, K.; HEINZMANN, B.M. Sesquiterpene peroxides from Senecio selloi and Eupatorium rufescens. Planta Medica, v.62; n.6, p.565-6, 1996.

RÜCKER, G.; MANNS, D.; SCHENKEL, E.P.; HARTMANN, R.; HEINZMANN, B.M. Triterpenes with a new 9-epicucurbitan skleton from Senecio selloi. Phytochemistry, v.52, n.8, p.1587-91, 1999.

RÜCKER, G.; MANNS, D.; SCHENKEL, E.P.; HARTMANN, R.; HEINZMANN, B.M. A triterpene ozonide from Senecio selloi. Archiv der Pharmazie, v.336, n.4-5, p.205-7, 2003.

SIQUI, A.C.; SAMPAIO, A.L.F.; SOUSA, M.C.; HENRIQUES, M.G.M.O.; RAMOS, M.F.S. Óleos essenciais - potencial antiinflamatório. Biotecnologia, Ciência e Desenvolvimento, v.16, p.38-43, 2000. 